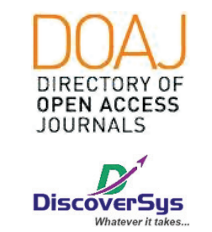

Published by DiscoverSys

\title{
Entitas histopatologi penderita perdarahan uterus terkait gangguan hormonal di Laboratorium Patologi Anatomi Rsup Sanglah tahun 2014 -2018
}

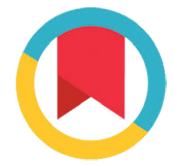

CrossMark

\author{
Ida Ayu Eugenia Natasha Blanco Oka, ${ }^{1 *}$ IGA Sri Mahendra Dewi, ${ }^{2}$ \\ Herman Saputra, ${ }^{2}$ Indraguna Pinatih ${ }^{3}$
}

\section{ABSTRACT}

Introduction: Dysfunctional uterine bleeding (DUB) is a major cause of a significant burden of health care for women, their families, and the community as a whole, leading to high morbidity for women who experience it. The purpose of this study is to determine the prevalence, characteristics of patients, and histopathological description in patients with DUB.

Method: This study uses a secondary data analysis method in the medical record data of patients with DUB who has been histopathologically examined at the Anatomy Pathology Laboratory, Sanglah General Hospital Denpasar in the period 2014 to 2018.

Result: From the period 2014 to 2018, 24 cases of DUB were found, the highest number was found in the pre menopause age
(41-50 years) in 15 cases (62.5\%), based on the type of estrogen related bleeding hormonal disorders in 17 cases (70.8\%), and 7 cases of progesterone related bleeding (29.2\%). The most histopathological type in the estrogen related bleeding group was 13 disordered proliferative phases (54.2\%). In the group with progesterone related bleeding, the highest histopathological picture was irregular shedding in 5 cases (20.8\%).

Conclusion: Estrogen related bleeding pattern still dominating the histopatological pattern in the dysfunctional uterine bleeding at Pathology Anatomy Laboratory, Sanglah General Hospital period 2014-2018.

Keywords: bleeding, uterine, hormonal disorder, histopathology, characteristic.

Cite This Article: Oka, I.A.E.N.B., Dewi, I.G.A.S.M., Saputra, H. 2019. Entitas histopatologi penderita perdarahan uterus terkait gangguan hormonal di Laboratorium Patologi Anatomi Rsup Sanglah tahun 2014 -2018. Intisari Sains Medis 10(2): 319-322. D0I: 10.15562/ism.v10i2.383

\section{ABSTRAK}

Latar Belakang: Perdarahan uterus disfungsional (PUD) adalah penyebab utama dari beban perawatan kesehatan yang signifikan bagi perempuan, keluarga mereka, dan masyarakat secara keseluruhan, menimbulkan angka morbiditas yang tinggi bagi kaum perempuan yang mengalaminya. Tujuan dari penelitian ini adalah untuk mengetahui prevalensi, karakteristik pasien, dan gambaran histopatologi pada pasien dengan PUD.

Metode: Penelitian ini menggunakan metode analisis data sekunder pada data rekam medis pasien dengan PUD yang dilakukan pemeriksaan histopatologi di Laboratorium Patologi Anatomi, RSUP Sanglah Denpasar pada periode tahun 2014 hingga 2018.

Hasil: Dari periode tahun 2014 hingga 2018 didapatkan 24 kasus PUD, rentangan usia terbanyak berada pada usia perimenopause
(41-50 tahun) yaitu sebanyak 15 kasus (62,5\%), berdasarkan tipe gangguan hormonal estrogen related bleeding sebanyak 17 kasus $(70,8 \%)$, progesterone related bleeding sebanyak 7 kasus $(29,2 \%)$. Tipe histopatologi terbanyak pada kelompok estrogen related bleeding adalah disordered proliferative phase sebanyak 13 kasus (54,2\%). Pada kelompok dengan progesterone related bleeding gambaran histopatologi terbanyak adalah Irreguler Shedding sebanyak 5 kasus $(20,8 \%)$.

Simpulan: Gambaran gangguan estrogen related bleeding masih menjadi gambaran histopatologi yang paling mendominasi pada kasus pendarahan uterus disfungsional di Laboratorium Patologi Anatomi, RSUP Sanglah Denpasar tahun 2014 hingga 2018.
${ }^{3}$ Bagian DKM-KP, Fakultas Kedokteran, Universitas Udayana, Bali-Indonesia.

${ }^{*}$ Correspondence to:

Ida Ayu Eugenia Natasha Blanco Oka, Program Studi Pendidikan Dokter, Fakultas Kedokteran, Universitas Udayana, Balio-Indonesia eugeniaoka.9f@gmail.com
Kata kunci: pendarahan, uterus, gangguan hormonal, histopatologi, karakteristik.

Cite Pasal Ini: Oka, I.A.E.N.B., Dewi, I.G.A.S.M., Saputra, H. 2019. Entitas histopatologi penderita perdarahan uterus terkait gangguan hormonal di Laboratorium Patologi Anatomi Rsup Sanglah tahun 2014 -2018. Intisari Sains Medis 10(2): 319-322. D0I: 10.15562/ism.v10i2.383

\section{PENDAHULUAN}

Perdarahan uterus disfungsional (PUD) adalah perdarahan uterus abnormal yang terjadi di dalam maupun diluar siklus menstruasi, yang disebabkan gangguan fungsional mekanisme kerja hipotalamus-hipofisis-ovarium-endometrium tanpa kelainan organik alat reproduksi. PUD paling 
banyak dijumpai pada usia perimenarche dan perimenopause. Perdarahan uterus disfungsional adalah penyebab utama dari beban perawatan kesehatan yang signifikan bagi perempuan, keluarga mereka, dan masyarakat secara keseluruhan.

Perdarahan Uterus Disfungsional (PUD) diketahui terjadi sekitar 20\% pada kelompok usia remaja, dan 50\% pada usia 40-50 tahun. ${ }^{1}$ Di RSUD Dr.Soetomo Surabaya pada tahun 2007 dan 2008 didapatkan angka kejadian perdarahan uterus abnormal sebanyak $12,48 \%$ dan $8,8 \%$ dari seluruh kunjungan poli kandungan. ${ }^{2}$

Pada penelitian yang dilakukan oleh Doraiswami (2011) di India, menemukan bahwa pada tahun 2005 hingga 2006 terdapat 620 pasien yang dating dengan klinis pendarahan uterus, dari keseluruhan pasien tersebut 409 orang terbukti mengalami lesi endometrium dan menjalani pemeriksaan histopatologis, dan ditemukan hanya $6 \%$ dari keseluruhan yang mengalami suatu pendarahan uterus disfungsional yang mencirikan suatu defek terkait estrogen (proliferative phase disorder). ${ }^{3}$

Dalam anovulasi PUD, feedback positif dari estradiol ke luteinizing hormone (LH) tidak bekerja dengan baik, yang akan membuat siklus menstruasi monophasic dan anovulasi. Karena tidak adanya midcycle LH surge, folikel atresia terjadi dan menjadi cystic, dan hanya menghasilkan estrogen tapi tidak menghasilkan progesteron. Selama siklus anovulasi ini, estrogen yang merupakan hasil dari folikel ovarium, menginduksi proliferasi endometrium. Kurangnya stabilisasi progestogenic, menyebabkan abnormal shedding pada endometrium. ${ }^{4}$ Pemeriksaan fisik sangat diperlukan untuk menentukan etiologi dari perdarahan dan untuk mengecualikan patologi vagina dan serviks. Keputihan, ukuran rahim dan kontur, dan nyeri pada uterus harus dicatat. Gambaran studi diperlukan untuk diferensial diagnosis. USG transvaginal adalah alat diagnostik lini pertama untuk mengidentifikasi kelainan struktural dalam Perdarahan Uterus Disfungsional. ${ }^{5}$

Agar patofisiologi PUD lebih mudah dipahami maka disfungsional ini dapat dibagi menjadi 2 kategori: estrogen-related (anovulatori) dan progesterone-related (ovulatori). Kategori PUD yang paling sering ditemukan adalah estrogen-related, dimana episode pendarahan yang berhubungan dengan rendahnya ovulasi dengan penurunan level estrogen endogenus. Gambaran histopatologi yang termasuk kategori estrogen-related adalah proliferative with glandular and stromal breakdown, disordered proliferative phase dan atrophy. Kategori kedua yang lebih jarang ditemukan yaitu PUD progesterone-related. PUD progesterone-related berhubungan dengan abnormalitas dari level progesteron endogenus. Gambaran histopatologi yang termasuk kategori progesterone-related yaitu luteal phase defects (LPD), irregular shedding dan abnormal secretory endometrium with breakdown of unknown etiology. ${ }^{6}$

Manajemen PUD harus berdasarkan etiologi yang mendasari dan tingkat keparahan perdarahan. Tujuan utama adalah pencegahan komplikasi, seperti anemia dan pembentukan kembali perdarahan siklus teratur. Dalam kasus yang mendasari sistemik, endokrin atau gangguan perdarahan, pasien mungkin memerlukan rujukan ke spesialis yang sesuai untuk evaluasi dan manajemen lebih lanjut. ${ }^{5}$

Penelitian ini bertujuan untuk memberikan gambaran histopatologi dan karakteristik pasien dari pendarahan uterus disfungsional di Bagian Patologi Anatomi, RSUP Sanglah Denpasar periode tahun 2014-2018.

\section{METODE}

Penelitian ini merupakan jenis penelitian deskriptif dengan metode penelitian analisis data sekunder yang bersumber dari data rekam medis Laboratorium Patologi Anatomi RSUP Sanglah Denpasar periode tahun 2014 sampai dengan 2018. Karakteristik yang dijabarkan dalam penelitian ini adalah usia, kejadian PUD pada setiap tahun penelitian, serta gambara histopatologis dari PUD, dan diagnosis klinis diluar diagnosis hasil patologi anatomi yang telah dibuat. Data kemudian dijabarkan dalam bentuk tabel.

\section{HASIL}

Penelitian ini menggunakan rancangan analisis data sekunder untuk menggambarkan kejadian Pendarahan uterus terkait gangguan hormonal dari tahun 2014 hingga 2018 di Laboratorium Patologi Anatomi, RSUP Sanglah Denpasar. Melalui penelitian ini terdapat 24 pasien dengan perdarahan uterus terkait gangguan hormonal yang kemudian dijabarkan berdasarkan karakteristik usia, dan gambaran histopatologi.

Karakteristik usia pasien dengan perdarahan uterus dengan gangguan hormonal pada rentangan usia 30-40 tahun sebanyak 1 kasus (4,2\%), rentangan usia 41-50 tahun sebanyak 15 kasus (62,5\%), rentangan usia 51-60 tahun sebanyak 7 kasus $(29,2 \%)$, dan usia $>60$ tahun sebanyak 1 kasus $(4,2 \%)$. Rentangan usia pasien dengan PUD yang terbanyak berada pada rentangan 41-50 tahun, sedangkan yang paling sedikit adalah pada rentangan 30-40 tahun dan lebih dari 60 tahun (Tabel 1).

Kejadian perdarahan uterus terkait gangguan hormonal dari tahun 2014 hingga 2018 adalah 24 kasus, pada tahun 2014 sebanyak 4 kasus, 
Tabel 1 Karakteristik Usia Pasien PUD

\begin{tabular}{lcc}
\hline Kelompok Usia & Frekuensi $(\mathbf{n = 2 4 )}$ & Persentase (\%) \\
\hline 30-40 tahun & 1 & 4,2 \\
$41-50$ tahun & 15 & 62,5 \\
$51-60$ tahun & 7 & 29,2 \\
$>60$ tahun & 1 & 4,2 \\
\hline
\end{tabular}

Tabel 2 Gambaran histopatologi esterogen-related bleeding dan progesterone-related bleeding

\begin{tabular}{lcc}
\hline Gambaran Histopatologi & $\begin{array}{c}\text { Frekuensi } \\
\text { (n=24) }\end{array}$ & $\begin{array}{c}\text { Persentase } \\
\text { (\%) }\end{array}$ \\
\hline Estrogen related bleeding & 17 & $70,8 \%$ \\
Disordered Proliferative Phase & 13 & $54,2 \%$ \\
Atrophy & 1 & $4,2 \%$ \\
Proliferative with glandular and stromal & 3 & $12,5 \%$ \\
breakdown & & \\
Progesterone related bleeding & 7 & $29,2 \%$ \\
Irreguler Shedding & 5 & $20,8 \%$ \\
$\begin{array}{l}\text { Abnormal secretory phase with glandular and } \\
\text { stromal breakdown }\end{array}$ & 2 & $8,3 \%$ \\
\hline
\end{tabular}

Tabel 3 Distribusi sampel berdasarkan diagnosis klinis

\begin{tabular}{lccc}
\hline $\begin{array}{l}\text { Diagnosis } \\
\text { Klinis }\end{array}$ & $\begin{array}{c}\text { Estrogen Related } \\
\text { Bleeding }\end{array}$ & $\begin{array}{c}\text { Progesterone Related } \\
\text { Bleeding }\end{array}$ & Total \\
\hline AUB & 16 & 7 & 23 \\
Menorraghia & 1 & - & 1 \\
& 17 & 7 & 24 \\
\hline
\end{tabular}

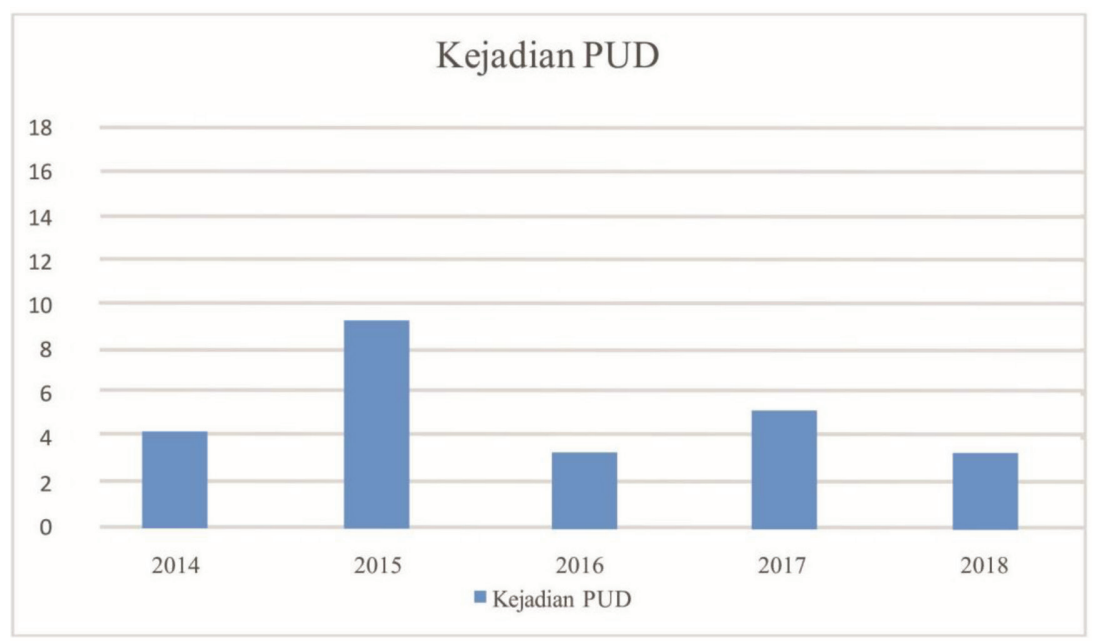

pada tahun 2015 sebanyak 9 kasus, pada tahun 2016 sebanyak 3 kasus, pada tahun 2017 sebanyak 5 kasus, dan 2018 sebanyak 3 kasus (Gambar 1).

Kejadian perdarahan uterus terkait gangguan hormonal dari tahun 2014 hingga 2018 adalah 24 kasus, pada tahun 2014 sebanyak 4 kasus, pada tahun 2015 sebanyak 9 kasus, pada tahun 2016 sebanyak 3 kasus, pada tahun 2017 sebanyak
5 kasus, dan 2018 sebanyak 3 kasus Kejadian perdarahan uterus terkait gangguan hormonal dari tahun 2014 hingga 2018 adalah 24 kasus, pada tahun 2014 sebanyak 4 kasus, pada tahun 2015 sebanyak 9 kasus, pada tahun 2016 sebanyak 3 kasus, pada tahun 2017 sebanyak 5 kasus, dan 2018 sebanyak 3 kasus

Diagnosis klinis yang dalam penelitian ini lebih banyak dicantumkan menggunakan istilah AUB (abnormal uterine bleeding) (Tabel 3). Hal ini dikarenakan pengkajian awal dilakukan di poli obstetri dan ginekologi sehingga seluruh pasien dengan klinis pendarahan uterus dibuatkan diagnosis AUB hingga diketahui lebih lanjut penyebab dari pendarahan uterus tersebut, selain dari pada itu dalam penelitian ini hanya terdapat satu kasus dengan diagnosis klinis menorraghia.

\section{PEMBAHASAN}

Pada penelitian ini ditemukan usia terbanyak pada pasien dengan PUD yaitu pada rentangan usia 41-50 tahun yaitu sejumlah 15 orang (62,5\%). Penelitian oleh Khadim dkk (2015) mengenai gambaran histopatologi spesimen jaringan pada pasien dengan pendarahan uterus terkait gangguan hormonal menemukan bahwa kelompok rentangan usia reproduktif (18-39 tahun) merupakan kelompok usia terbanyak yang mengalami PUD (56,40\%), kemudian disusul oleh kelompok usia 40-50 tahun yaitu dengan proporsi $32,70 \%$, rerata kelompok usia subjek pada penelitian tersebut adalah 39 tahun. Penelitian lain oleh Doraiswami dkk mengenai gambaran patologi pada pasien dengan pendarahan uterus disfungsional pada 409 subjek di India menemukan bahwa dua kelompok usia dengan angka kejadian tertinggi adalah usia 41-50 tahun (137 kasus) dan usia 31-40 sebanyak 116 kasus. Temuan tersebut merupakan temuan yang serupa dengan yang ditemukan peneliti dimana insiden PUD lebih banyak pada rentangan usia 41-50 tahun (usia perimenopause). ${ }^{3}$

Rentangan usia 41-50 tahun merupakan suatu rentangan usia yang dimasukkan dalam kategori perimenopause. Pada kondisi perimenopause terjadi suatu perubahan hormonal yang akan diarahkan menuju ke tahap menopause, hal ini memberikan dampak terhadap struktur histopatologis yang ada dalam endometrium. Pada suatu studi yang dilakukan oleh Khadim dkk bahwa pada kelompok usia perimenopause (usia 40-50 tahun) lebih banyak terjadi perubahan struktur histologi pada endometrium yaitu proliferative endometrium sehingga keadaan ini menjadi suatu alasan biologis mengapa angka kejadian cenderung tinggi pada rentangan usia tersebut. ${ }^{7}$ 
Pada penelitian ini estrogen related bleeding lebih banyak dijumpai dibandingkan dengan progesterone related bleeding yaitu dengan proporsi $70,8 \%$, dan gambaran histopatologis yang paling banyak ditemukan adalah proliferative phase disorder.

Penelitian oleh Khadim dkk (2015) yang melakukan biopsy pada 101 wanita dengan pendarahan uterus menemukan adanya gambaran histopatologi yang beragam, temuan proliferative endometrium sebanyak 52,5\% (52 kasus). ${ }^{7}$ Penelitian lain oleh temuan tersebut merupakan temuan serupa dengan yang ditemukan oleh peneliti. Penelitian lain oleh Bulletti dkk yang melakukan observasi perubahan gambaran histopatologi pada 105 pasien dengan PUD yang mendapat terapi GnRH agonis menemukan gambaran proliferative phase dan glandular hyperplasia adalah gambaran yang paling banyak ditemui. $^{8}$

Penelitian lain yang dilakukan oleh Bertrand dkk mengenai hubungan gambaran histologis PUD terhadap luaran rekurensi pada total 136 pasien di Michael Reese Hospital, Chicago, menemukan bahwa gambaran morfologis yang ditemukan adalah secretory (66\%) dan proliferative (34\%). Sedangkan apa bila ditinjau dari kejadian rekurensi dalam 48 bulan, dari total 90 orang (66\%) yang memiliki gambaran histologis secretory mengalami rekurensi pendarahan sebanyak 27 orang (30\%) dan dari total 46 orang (34\%) dengan gambaran morfologis proliferative hanya 10 orang $(21,7 \%)$ yang mengalami rekurensi pendarahan. ${ }^{9}$

Adanya penurunan konsentrasi estrogen menyebabkan kegagalan dalam menjaga struktur endometrium yang kemudian menyebabkan terjadinya suatu irregular shedding dari endometrium. Perubahan hormonal seperti hal tersebut lebih jauh lagi akan menyebabkan perubahan lingkungan endometrium yang berpotensi untuk meningkatkan terjadinya apoptosis seiring dengan menurunnya level estrogen, yang kemudian akan menimbulkan gangguan dalam fase proliferative (proliferative phase disorder). ${ }^{10}$ Adanya suatu penurunan estrogen yang berkepanjangan nantinya akan menyebabkan adanya suatu breakdown of endometrial glands and stroma. ${ }^{11,12,13}$

Kelemahan dalam penelitian ini yaitu data yang diambil hanya berdasarkan rekam medis dan hanya berdasarkan gambaran deskriptif, sehinngga belum dapat mengetahui hubungan sebab akibat dari faktor-faktor karakteristik yang mempengaruhi gambaran histopatogi.

\section{SIMPULAN}

Dalam penelitian ini usia terbanyak pada pasien yang mengalami pendarahan uterus disfungsional dijumpai pada rentangan 41-50 tahun, angka kejadian paling tinggi pada tahun 2015 yaitu sebanyak 9 kasus, dan jenis gambaran histologipatologi terbanyak adalah estrogen related bleeding dengan gambara tikipkal disorder of proliferative phase.

\section{DAFTAR PUSTAKA}

1. Fraser IS, Langham S. Health-related quality of life and economic burden of abnormal uterine bleeding. Expert Rev Obstet Gynecol. 2009;4:179-89.

2. Hendarto H. Gangguan Haid/Perdarahan Uterus Abnormal. In: Mochammad Anwar, Ali Baziad, R. Prajitno Prabowo, editors. Ilmu Kandungan ( $3^{\text {rd }}$ ed). Jakarta; PT Bina Pustaka Sarwono Prawirohardjo, 2011. p. 162-9.

3. Doraiswami S, Thanka J, Shalinee R, Aarthi R, Jaya V, Kumar PV. Study of endometrial pathology in abnormal uterine bleeding. The Journal of Obstetrics and Gynecology of India. 2011;61(4):426-430.

4. Deligeoroglou E, Karountzos, V, Creatsas G. Uterine Bleeding in Pediatric and Adolescent Gynecology. Gynecological Endocrinology. 2013;29(1):74-78.

5. Gray SH, Emans SJ. Abnormal vaginal bleeding in adolescents. Pediatr Rev. 2007;28:175-182.

6. Mazur M, and Kurman RJ. Diagnosis of endometrial biopsies and curettings: a practical approach. Arch J Med Sci. 2005;3(2):18-23.

7. Khadim MT, Zehra T, Ashraf HM. Morphological study of pipelle biopsy specimens in cases of abnormal uterine bleeding. J Pak Med Asoc. 2015;65(7):705-709.

8. Bulleti C, Flamigni C, Prefetto RA, Polli V, Giacomucci E. Dysfunctional uterine bleeding (DUB). Annals New York Academy of Science. 2011;6(2):80-90.

9. Bertrand ND. Dysfunctional uterine bleeding: relation of endometrial histology to outcome. Amer J Obstet Gynecol. 2008;109(1):103-107.

10. Rekha K, Malini A, Xavier R, Baba K. Apoptosis in endometira of dysfunctional uterine. Med J Malaysia. 2004;60(1):41-45.

11. Espindola D, Kathleen AK, Fischer EG. Management of abnormal uterine bleeding and the pathology of endometrial hyperplasia. Obstet Gynecol Clin N Am. 2007;34:717-737.

12. Adnyana IBP, Liwang F, Negara KS, Manuaba IBP, Bhargah A, Prabawa IPY. Clinical risk factor of preeclampsia: a five-year retrospective study in Bali Royal Hospital, Bali-Indonesia. Gineco.eu. 2018;14(53):89-93. DOI: 10.18643/gieu.2018.89.

13. Megadhana I, Suwiyoga K. Stage III-IV Uterine Prolapse Risk Factors: Sacrouterine Ligaments High Estrogen Receptor Alpha and Collagen III Expression and Low Elastin Expression. Bali Medical Journal. 2016;5(1):91-97. DOI: $10.15562 /$ bmj.v5i1.275

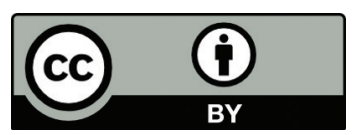

This work is licensed under a Creative Commons Attribution 